Management of Traffic Accidents in Shanghai City Professor Hong-Qi Zhang, MD

Disaster Medicine Editor Committee of China, Shanghai, PEOPLE'S REPUBLIC OF CHINA

China has $2.2 \%$ of the number of motor driven in the world, but automobile accidents in China comprise $9 \%$ of the automobile accidents in the world. Currently, 86,000 deaths result from traffic accidents annually. Shanghai is one of the largest cities of the world with a population of $13,000,000$ inhabitants. The average density of population is $>1,000$ persons per $\mathrm{km} 2$, and that in the central part of the city, it is $>10,000$ persons per $\mathrm{km} 2$. Currently, more than 2,000,000 people move through Shanghai daily. The total number of passengers using buses during 1995 was over 5,500 million.

Statistics of the past five years indicate that the number of traffic accidents exceeded the past records by 60,000 cases with two persons killed daily (in the whole of China, 1 person is killed by accidents every 6 minutes). Tables 1 and 2 present these traffic accident statistics.

\begin{tabular}{|c|c|c|c|}
\hline Year & $\begin{array}{l}\text { Number of } \\
\text { Accidents }\end{array}$ & $\begin{array}{l}\text { Number of } \\
\text { Injured }\end{array}$ & $\begin{array}{l}\text { Number of } \\
\text { Deaths }\end{array}$ \\
\hline 1994 & 18,475 & 10,059 & 1,514 \\
\hline 1995 & 20,074 & 9,500 & 1,164 \\
\hline 1996 & 8,736 & 8,991 & 947 \\
\hline 1997 & 7,621 & 4,699 & 607 \\
\hline 1998 & 7,524 & 4,450 & 594 \\
\hline Total & 62,430 & 37,699 & 4,826 \\
\hline
\end{tabular}

Table 2-Statistics of Traffic Accidents in China from 1994 to 1998

Year

1994

1995

1996

1997

1998

Total

$\begin{gathered}\text { Number of } \\ \text { Accidents }\end{gathered}$
298,147
276,071
258,030
250,297
264,817
$1,347,362$

$\begin{gathered}\text { Number of } \\ \text { Deaths }\end{gathered}$
53,439
54,814
50,441
49,271
53,292
261,257

From the above traffic accidents, the following characteristics can be identified:

1. Of all the persons killed in traffic accidents, $85 \%$ are below the average of 40 years of age

2. Prehospital mortality rate from traffic accidents was $66 \%$

3. $60 \%$ of traffic accidents are related to bicyclists

Improvement of prehospital first aid and emergency facilities has decreased the rate of mortality and injuries by traffic accidents in recent years. The Shanghai First Aid Central Station (SFACS) possesses 173 ambulances and is staffed by 517 specialists. The facilities of the new resuscitation ambulances, called a "Movable ICU", consists of a cardiopulmonary monitor, ventilator, emergency drugs, and other resuscitative equipment. The ambulance also has an excellent communication device that can connect with any part of the communication network in Shanghai City. Altogether, 110,889 persons requiring first aid were transported by SFACS in 1996 . The number of the wounded by traffic accidents and other disasters (e.g., burn accidents, intoxication, drowning, etc.) was 26,681 with 318 persons found dead before hospitalization.

All severe trauma patients should be transported to the identified hospital in Shanghai. Every central hospital in Shanghai carries out the actions to set up a resuscitative department so as to accept masses of critically wounded casualties in time based on the conditions of the disaster. The functions of a resuscitative department are to sort all of the critically wounded from ordinary ones, resuscitate them, and render all supportive treatments required. Their functions include cardiopulmonary resuscitation, immediate treatment of life threatening respiratory failure, organ injuries, and stopping the loss of blood. Initial management of fractures and injuries from these disasters should be referred to the orthopedic department.

Key words: accidents; ambulances; deaths; hospitals; injuries; resuscitation; staff; traffic; trauma; treatment Prehosp Disast Med 2001;16(2):s88.

\section{Computer-aided Patient Management on the Field: A New Facet of French School for Disaster Medicine P.Zellner; ${ }^{1}$ G.MarchaP}

Centre Hospitalier de Chambery, Chambery Cedex, FRANCE

In recent years, network technology has made much progress. It has provided us with an easier management of our parients at the disaster scene. This work highlights French rescue organisation and led to the creation of an application program that provides a real management scenario. Above all, it provides effective information in real time for all of the contributors to a rescue plan. The design stage (hardware and software) of the project is completed. Trials are scheduled for May or June 2001 during disasters exercises.

We will present this application program, the product of two years of work. We hope to convince physicians of the great potential of these new network technologies for their practise.

Key words: computer assistance; field; management; networks; patients; technology

E-mail: 1. Samu 73@ch - chambery.fr 2.gmarchal@appligos.com

Prehosp Disast Med 2001;16(2):s88.

\section{First Aid for Gunshot Wounds in High Altitude Areas} Professor Hong-Qi Zhang, $M D$

Disaster Medicine Editor Committee of China, Shanghai, PEOPLE'S REPUBLIC OF CHINA

Introduction: We will discuss special prehospital treatment of the mass numbers of victims of firearms that had not been considered previously. Since 1990, we have attended to the research work of gunshot wounds in such area as $\mathrm{Xi}$ Zang, where the plateau is about 4,000 meters $(13,123$ feet) above sea level (mean atmospheric pressure $=463$ 
$\mathrm{mmHg}, \mathrm{pO}_{2}=97 \mathrm{mmHg}$ ), We received 574 victims and their wound location, type, and result (died of wound or killed in action) are shown in Table 1.

Table 1-Number and percentage of gunshot wounds by location, type and result

\begin{tabular}{|c|c|c|c|c|c|c|}
\hline \multirow[t]{2}{*}{$\begin{array}{l}\text { Anatomical } \\
\text { Location }\end{array}$} & \multicolumn{2}{|c|}{$\begin{array}{c}\text { Non- } \\
\text { Penetrating } \\
\text { Wound }\end{array}$} & \multicolumn{3}{|c|}{$\begin{array}{l}\text { Penetrating } \\
\text { Wound }\end{array}$} & \\
\hline & $N$ & $(\%)$ & & & $\%)$ & \\
\hline Head & 35 & $(6.0)$ & & & 0.7 & \\
\hline Chest & 25 & (4.3) & & & 1.4 & \\
\hline Abdomen & 26 & (4.5) & & & 7.4 & \\
\hline Perineum & 5 & 0.9 & & & 1.9 & \\
\hline $\begin{array}{l}\text { Upper } \\
\text { Extremity }\end{array}$ & 48 & (8.3) & & & 2.1 & \\
\hline $\begin{array}{l}\text { Lower } \\
\text { Extremity }\end{array}$ & 45 & $(7.8)$ & & 1 & 5.6 & \\
\hline Other & 23 & (3.9) & & 3.3 & & \\
\hline Total & 184 & $(32.0)$ & & & $9.1)$ & \\
\hline \multirow[t]{2}{*}{$\begin{array}{l}\text { Anatomical } \\
\text { Location }\end{array}$} & \multicolumn{2}{|c|}{$\begin{array}{l}\text { Died } \\
\text { of } \\
\text { Wound }\end{array}$} & \multicolumn{2}{|c|}{$\begin{array}{l}\text { Killed } \\
\text { in } \\
\text { Action }\end{array}$} & \multicolumn{2}{|c|}{$\begin{array}{c}\text { Number } \\
\text { of } \\
\text { Cases }\end{array}$} \\
\hline & $N$ & $(\%)$ & $N$ & $(\%)$ & $N$ & $(\%)$ \\
\hline Head & 4 & $(0.7)$ & 58 & (10.1) & 97 & (16.8) \\
\hline Chest & 3 & (0.5) & 64 & (11.1) & 91 & (15.8) \\
\hline Abdomen & 8 & (1.4) & 44 & (7.6) & 69 & $(12.0)$ \\
\hline Perineum & 5 & $(0.9)$ & 16 & (2.8) & & \\
\hline $\begin{array}{l}\text { Upper } \\
\text { Extremity }\end{array}$ & 2 & $(0.3)$ & 5 & $(0.9)$ & 118 & $(20.5)$ \\
\hline $\begin{array}{l}\text { Lower } \\
\text { Extremity } \\
\text { Other }\end{array}$ & 8 & (1.4) & 18 & (3.1) & 135 & (23.4) \\
\hline Total & 25 & (4.4) & 217 & (37.6) & 574 & $(100.0)$ \\
\hline
\end{tabular}

Effect of Topography and Climate: The high altitude climate of $\mathrm{Xi}$ Zang is varied and its topography consists of immense forests, precipitous cliffs, and deep valleys so that travel over the mountains is dangerous. Every year, between spring and summer, mountain floods, falling rocks or rock slides, and avalanches usually occur there. The communications in this area often have been interrupted by these calamities. The field hospital is located far away (about 600 to 800 kilometers) from the calamitous area. Therefore, it is very difficult to have the wounded transported to the field hospital and given first aid treatment. Statistics show that only $18.7 \%$ of the wounded can be transported to the field hospital within 24 hours.

Table 2-Effects of altitude

$\begin{array}{lcccc}\begin{array}{l}\text { Research Altitude } \\ \text { area }\end{array} & \begin{array}{c}\text { Altitude } \\ \text { (meters) }\end{array} & \begin{array}{l}\text { Barometric } \\ \text { (feet) }\end{array} & \begin{array}{l}\mathbf{p O}_{2} \\ \text { Pressure } \\ \text { (mmHg) }\end{array} \\ & 3,175 & 10,417 & 500.5 & 104.90 \\ \text { Ton } & 5,110 & 16,765 & 400.5 & 83.84 \\ \text { Hang } & 4,366 & 14,324 & 439.0 & 92.0 \\ \text { Don } & 4,280 & 14,024 & 446.0 & 93.48\end{array}$

Pathophysiology Character and Clinical Signs of Wounds at High Altitude: The adverse circumstances with harsh climates at low atmospheric pressure cause pulmonary artery hypertension, low capacity of lungs, hypoxemia, and overload of the right heart. As a result, pulmonary edema appears. At sea level, the percentage of oxygen in the atmosphere is $20.95 \%$ and the $\mathrm{pO}_{2}$ at sea level is 159.2 $\mathrm{mmHg}$. At an altitude of 10,000 feet (3,048 meters), where the barometric pressure is $523 \mathrm{mmHg}$, the percentage of oxygen remains $20,95 \%$, but the $\mathrm{pO}_{2}$ decreases to 109.6 $\mathrm{mmHg}\left(\mathrm{pO}_{2}=20.95 \%\right.$ X $\left.523 \mathrm{mmHg}=109.6 \mathrm{mmHg}\right)$.

The main clinical appearance of victims are due to hypoxemia. It is caused by an inadequate $\mathrm{pO}_{2}$ in inspired air and a ventilation defect with the result of in an oxygen deficiency in the tissues. The condition of victims is usually serious due to a majority of them presenting with penetrating wounds. Penetrating wounds cause this form of hypoxia with blood loss and anemia. The initial respiratory system response to hypoxia in the wounded, is an increased rate and depth of ventilation. Hyperventilation results in reduction of $\mathrm{pCO}_{2}$ causing respiratory alkalosis and a shift of the oxyhemoglobin association curve to the left. The result allows an increased binding of oxygen with hemoglobin for transport to the tissue.

At an altitude of 20,000 feet (6,096 meters), the oxygen saturation of the hemoglobin, drops to $70 \%$, and the physical findings include an inability to remain upright, jerking of upper limbs, seizures, unconsciousness, coma, and death. For these reasons, then, the general condition of the wounded is quite serious.

Character of Wound Ballistics: The character of wound ballistics of casualties in the High Altitude area is related to the high percentage of cases with penetration. Thus, the number of patients with penetrating wounds occupy $54.1 \%$ of the total number of casualties. While the proportion of penetrating wounds reached $70 \%$ of the killed in action (KIA), the entrance of ballistics is small and exits large, the wound will be combined with serious edema and contamination. In bacteriological examination of wound ballistics at an early stage, staphylococcus aureus generally will be found. Low atmospheric pressure and $\mathrm{pO}_{2}$ make the anaerobic bacteria grow and propagate rapidly. Therefore, the incidence of gas gangrene rate increased to $3.4 \%(0.44 \%$ in Korean War).

Treatment. The natural state of high altitude is perilous. The statistics of our groups are self-explanatory and the self-aid of the wounded is only $9.6 \%$ (21.2\% in Korean War).

Supplemental Oxygen: The effects to treat hypoxia of the wounded at high altitude is the goal of oxygen therapy, which increases the alveolar concentration of oxygen and decreases myocardial work.

$\begin{array}{lccc}\begin{array}{l}\text { Table 3-The effects of } \\ \text { Altitude } \\ \text { (feet) }\end{array} & \begin{array}{c}\text { Altitude } \\ \text { (meters) }\end{array} & \begin{array}{c}\text { oxygen inhalation at altitude } \\ \mathrm{pO}_{2} \\ (\mathrm{mmHg})\end{array} & \begin{array}{c}\text { Post } 100 \% \\ \text { Oxygen inhalation } \\ \mathrm{pO}_{2}(\mathrm{mmHg})\end{array} \\ 36,000 & 10,930 & 39.4 & 170.9 \\ 42,000 & 12,802 & 26.8 & 128.3 \\ 46,000 & 14,021 & 22.2 & 105.9\end{array}$

Low Altitude Therapy: For this reason, to utilize high technological communication and helicopters to carry the wounded in the high altitude area is preferable to the original transportation means, is not limited by varied topography, and can conveniently transport the wounded to hospitals at lower altitude. The wounded can be resuscitated in a timely manner and complications from altitude stress and 
mountain hypoxemia can be decreased to a great extent. Key words: altitude; ballistics; gangrene; gunshots; helicopters; hypoxemia; hypoxia; oxygen; penetration; prehospital; saturation; transportation; wounds

Prehosp Disast Med 2001;16(2):s90.

\section{Treatment of Shock Resulting from Abortion Using Misoprostol: A Case Report Zhang Lin; et al.}

Taian Taishan District Family-Planning Service Station, Shandong, PEOPLE'S REPUBLIC OF CHINA

A woman who was five weeks pregnant ingested mifeiston with misoprostol for induction of an abortion. She developed shock 10 minutes after taking three pieces of misoprostol. By way of a series of emergency treatments, the patient improved from her critical condition and an abortion followed. We concluded that the medicine that induced the shock was misoprostol and not the others. In clinical settings where abortions are medicine-induced, it is important to monitor the patient closely after dosing in order to avoid this complication.

Key words: abortion, complications; induction; medicine; mifeiston; misoprostol; shock; treatment

Prebosp Disast Med 2001;16(2):s90.

\section{Development and Analysis of a Peacetime and Wartime Portable Ambulance Zbang Wencai; Zuo Fengting}

No. 252 Hospital of PLA, Hebei Baoding, PEOPLE'S REPUBLIC OF CHINA

This paper mainly concerns a special portable ambulance used in peacetime or wartime that can be assembled using some new systems. The purpose, necessity, feasibility, and operation instructions are discussed in detail. The stretcher not only can alleviate the suffering of the patients whose bed must be exchanged at the time of medical treatment, but also reduces the labor intensity of medical personnel. Specifically, used as an unsophisticated, operation table or an examination bed in wartime, or, in exceptional cases such as fighting against natural calamities, it may be used in urgent operations and early surgical treatment. In short, it may be useful in many fields.

Key words: ambulance, portable; examination bed; stretcher; surgical bed

Prehosp Disast Med 2001;16(2):s90.

\section{The Management of Mass Casualties of Serious Earthquakes in China Yi Bin Zhang}

Fu Dan University, Zhong Shan Hospital, Shanghai, PEOPLES REPUBLIC OF CHINA

Since 1950, China has endured 11 serious (Richter magnitude $>7$ ) earthquakes. Statistics indicate that more than 280,000 people died, and approximately $1,000,000 \mathrm{~m} 2$ of houses were destroyed. Recently, we rendered first aid to those injured in the most serious earthquake in the TongShan area of Northern China, where 242,000 inhabitants were killed and 164,000 were either slightly or seriously wounded. Almost all of the buildings in the city, high and low, were demolished. These buildings certainly included water and electricity supply systems and medical organizations.

At the time, there were 218 emergency medical support groups from all over the country with memberships of 19,772 medical practitioners. They received 145,800 wounded persons. Among them, 63,400 were serious and 29,600 were in critical condition. Both had to receive emergency care. Statistics showed that $92 \%$ of wounded were treated with debridement, and others were separated into different categories with different treatments as following: $3.9 \%$ were treated with laparotomy; $0.13 \%$ with intestinal repair; $0.26 \%$ with splenectomy; $1.5 \%$ with fracture reduction; $0.2 \%$ with amputation; $0.13 \%$ with laminectomy; and 1.14\% with other operation. From 28 July to August 1996, altogether 15,351 wounded persons were transported to hospitals in other places by air and 72,818 to other places by train.

Key words: deaths; debridement; earthquakes; emergency; injured; Japan; laparotomy; surgery; Tong-Shan Prebosp Disast Med 2001;16(2):s90.

\section{Effects of Cytokine Gene Therapy on Prolonging Survival Time of Allografted Skin Zheng Jianghong; Gu Caizhi; Lin Zbibao; et al.} Department of Burn and Plastic Surgery, General Hospital of Urumqi, Urumqi, PEOPLE'S REPUBLIC OF CHINA

Objective: To explore the role of cytokine gene therapy on prolonging the survival time of allografted skin after scalding in a murine model.

Methods: The Interleukin-10 (IL-10) gene was employed as therapeutic objective gene and fibroblast was used as a carrier cell. The gene transcription technique was adopted to establish an experimental murine model in which fibroblast-mediated gene therapy was used to prolong the allografted skin survival time after scalding. IL-10 was transferred into fibroblastocyte (NIH3T3) by reverse transcriptive virus vector. The mice were grafted with alloskin after scalding. In addition, collagen capsulized NIH3T3IL-10 cells were implanted intraperitoneally into the mice so as to observe its influence on allografted skin survival time and on the changes of their main internal organs.

Results: Cytokine gene therapy prolonged the survival time of allografted skin $(p<0.01)$ without any evident detrimental effect on the internal organs.

Conclusion: These results indicate that skin allograft rejection could be inhibited and the survival time prolonged with the implantation of the fibroblastocyte-transferred IL-10 gene.

Key words: allograft; fibroblastocyte; gene; interleukin-10; scalding; skin; survival time

Prebosp Disast Med 2001;16(2):s90. 